Social Sciences on Contemporary Turkey

$20 \mid 2015$

Heritage Production in Turkey. Actors, Issues, and

Scales - Part II

Being sick of politics: The production of dengbêjî as Kurdish cultural heritage in contemporary Turkey

Marlene Schäfers

CpenEdition

Journals

Electronic version

URL: http://journals.openedition.org/ejts/5200

DOI: $10.4000 /$ ejts.5200

ISSN: $1773-0546$

Publisher

EJTS

Electronic reference

Marlene Schäfers, « Being sick of politics: The production of dengbêjî as Kurdish cultural heritage in contemporary Turkey », European Journal of Turkish Studies [Online], 20 | 2015, Online since 01 March 2015, connection on 16 February 2020. URL : http://journals.openedition.org/ejts/5200 ; DOI :

$10.4000 /$ ejts. 5200

This text was automatically generated on 16 February 2020.

(C) Some rights reserved / Creative Commons license 


\title{
Being sick of politics: The production of dengbêjî as Kurdish cultural heritage in contemporary Turkey
}

\author{
Marlene Schäfers
}

My thanks are due to Yael Navaro-Yashin, Banu Karaca and Jeremy Walton for providing invaluable feedback on earlier drafts of this paper. I am also indebted to the anonymous EJTS reviewers for their critical engagement with the subject matter.

"I am sick of politics [siyaset]!" Hatice ${ }^{1}$ exclaimed with a sense of exasperation as we were trying to warm up over tea after the performance she had given together with a number of other women dengbêjs [Kurdish bards] at the occasion of the International Day for the Elimination of Violence against Women on the 25 November, 2012. The rally had been organized by the Democratic Free Women's Movement [Demokratik Özgür Kadin Hareketi, DÖKH], the PKK-aligned wing of the Kurdish women's movement, and the seemingly never-ending speeches by various women politicians had not only made the cold seep into our bodies but also cut into the dengbêjs' performance time. Angry over having been cut short at a rally yet another time Hatice exclaimed with a mixture of passion and frustration: "I want to do art [sanat], not politics [siyaset]!" She felt that Kurdish culture and arts - paradigmatically embodied, in her view, by dengbêjs like herself - had lost out not only against the upbeat tempo of popular pieces like Aynur Doğan's "Keça Kurdan" that had been pounding out from the large loudspeakers during the rally, but also against the professional politicians of the Kurdish Peace and Democracy Party (BDP) ${ }^{2}$ and their speeches. But wasn't being a dengbêj and thereby preserving Kurdish traditions in itself a measure supporting the Kurdish cause, Hatice now asked us. Were they not supporting the aims of the Kurdish women's movement, as women dengbêjs out there on a stage in the freezing cold? Why then were they not given the attention she felt they deserved? Turning to me, Münevver, a great admirer of dengbêjs and their kilams ${ }^{3}$ with a passion for Kurdish literature and poetry, felt the 
need to explain. It is a general problem of the Kurds as a people that they don't know how to keep things separate, she told me, and seemed to imply that this failure at proper separation was somehow responsible for the historical predicament of Kurdish subaltern status and possibly even for the Kurdish failure at establishing an independent nation-state. "Politics, militarism, music, art, culture; they should be separate from each other," she said, "but we Kurds, we constantly mix them up!"

2 Taking Hatice's rejection of politics in the name of art and Münevver's simultaneous insistence on boundary maintenance as my points of departure, in what follows I seek to investigate some of the complexities and paradoxes of contemporary Kurdish heritage production in Turkey through the prism of dengbêjî. As this article will argue, Hatice's exasperation at the continual encroachment of politics upon the art of dengbêjî has to be understood as an effect of the particular ways in which dengbêjî has become codified as cultural heritage and thus as the authentic essence of Kurdish culture. Such an understanding, in turn, allows for a continual slippage between cultural heritage understood as, on the one hand, marking the essence of the Kurdish nation and being therefore of an inherently political nature and, on the other hand, constituting a non- or prepolitical realm of folkloric engagement with ethnic traditions. Following Banu Karaca (2009), I suggest that it is precisely this slippage which lends the concept of cultural heritage its particular political productiveness and which may therefore account for the ways in which dengbêjî has become the central object of a number of heated debates and contestations.

3 By marshalling ethnographic material from my fieldwork with women dengbêjs in the region of Van who advocate dengbêjî as a form of cultural practice separate from politics, I do not mean to suggest that these women were in any way representative of all dengbêjs, of all Kurdish women in general or of all Kurdish cultural activists. This was in fact hardly the case: more often than not, women like Hatice or Münevver find themselves in a minority position within a context where everyday life - including cultural and artistic production - is intensely and consciously politicized. Given a longstanding and engrained history of systematic and violent persecution, repression, denial and assimilation of all matters Kurdish by the Turkish state, Kurdishness has effectively been rendered an inherently and inescapably political subject position in Turkey today. Moreover, the Kurdish political movement in its struggle to counter state repression and denial, has in its own turn insisted that Kurdishness is a thoroughly political state of existence. As a result, the terrain on which any cultural or artistic production takes place in Turkish Kurdistan has become so thoroughly suffused with politics that invoking cultural heritage here as a sphere that ought to be free from politics requires, as this article will proceed to show, a certain amount of social labour. This is not to say that the kind of cultural activism advocated by women like Hatice and Münevver is in any way apolitical; rather, their engagement may be regarded as a form of "nongovernmental politics" as developed by Michael Feher. Feher describes nongovernmental politics as a form of politics that explicitly does not aspire to govern and which derives its legitimacy precisely from this abstinence, thus making for nongovernmental actors' frequent downplaying or denial of the political character of their endeavours. Such claims, writes Feher, do however not enable nongovernmental activists "to eschew the conflicts and transcend the power relations that make up the social fabric in which they intervene" and therefore make their engagement "no more apolitical than governmental" (Feher 2007: 13). Referring specifically to the Turkish 
context, Jeremy Walton has argued that here the kind of nongovernmental politics described by Feher "is not a fait accompli but an achievement" (Walton 2013: 184) given Turkey's strong state tradition. Taking up Walton's suggestion, in what follows I therefore seek to explore how rendering the politics of culture nongovernmental in Turkish Kurdistan equally constitutes an achievement that has to labour against not only the Turkish state but oftentimes also against the Kurdish political movement.

4 A word of caution is necessary here. Given that the Turkish state has, over the last several decades, increasingly turned to a particular form of liberal multiculturalism in an attempt at managing its "Kurdish question" (alongside its other ethnic and religious "minorities"), invoking Kurdish cultural heritage as a sphere free from politics plays with the ambiguous risk of replicating - even if unintentionally - the state's agenda of rendering Kurdish culture a matter of depoliticized folklore. By attending to the ways in which some of my interlocutors sought to straddle this fraught political and cultural landscape and paying close attention to the different registers of politics they evoked in order to do so, this article seeks to outline the fault lines that characterize attempts at codifying and institutionalizing a stable field of Kurdish cultural heritage in Turkey today. Moreover, the article will also highlight some of the specifically gendered dynamics involved in this undertaking and ask what opportunities a liberal imagination of dengbêjî as the exercise of authentic Kurdish culture free from politics may hold for women dengbêjs in particular.

5 But let me begin with a brief account of the ways in which dengbêjî has come to be conceptualized as the paradigmatic form of Kurdish cultural heritage and how such a conceptualization lends it a particular form of political productivity.

\section{The authentic essence of Kurdishness: Dengbêjî as cultural heritage}

The idea that dengbêjî constitutes the essence of authentic Kurdish culture and that dengbêjs are consequently its main transmitters is relatively recent. The term dengbêjî itself is indicative of the social labour that had to go into turning this disparate field of persons, practices and knowledge into a delimited sphere of culture, a coherent and defined entity that could then become the object of any conversation, debate or argument. As Clémence Scalbert-Yücel has noted, in Kurdish the term dengbêji $\hat{1}^{4}$ "sounds a bit artificial" (Scalbert-Yücel 2009: 14). Why should this be the case? Even though I have not been able to determine with any exactitude when the term first entered into widespread use in either written or oral Kurmanji Kurdish, my own observations as well as those of other researchers indicate that the term has a relatively recent history, which seems to have evolved in response to a need to designate the object it denotes - "minstrelsy," "singing" or "the art of being a dengbêj," as defined by Michael Chyet (2003) - as this has come into being as a delineated object. While the noun dengbêj, designating the singer or storyteller as a person, is a longestablished term, ${ }^{5}$ the widespread use of the related dengbêjî as a noun denoting in abstract fashion the body of knowledge, as well as the practice that makes one a dengbêj, seems to be a relatively recent phenomenon. Today, the term dengbêjî (or dengbejlik in Turkish) appears quite commonly in written publications and is used frequently in spoken discourse by academics, intellectuals, and many dengbêjs themselves, especially those who have been in contact with Kurdish cultural 
institutions. Throughout my fieldwork I found that the term was much less commonly used, however, by many of the illiterate and elderly women living in the countryside, who would more often employ constructions with dengbêj as the grammatical subject (e.g. "dengbêjs do..." or "dengbêjs say...") rather than speaking abstractly about dengbêjî as a body of knowledge (as implied by constructions like "dengbêjî is..." or "I do dengbêjî"). ${ }^{6}$ I interpret this shift in language as indicative of the coming-into-being of an abstract and disembodied understanding of what a dengbêj does as an identifiable object of knowledge-cum-practice, something that one can conceive of separately from the dengbêj as the practitioner herself. This shift, moreover, appears symptomatic of broader changes in the understanding of Kurdish "culture" as a delineated field distinct from the ordinary practices of everyday life.

7 Attempts at delineating, codifying and documenting Kurdish culture as a distinct field can be traced back to the beginnings of modern Kurdish nationalism in the early twentieth century, when Kurdish intellectuals self-consciously sought to create a canon of Kurdish language, folklore and traditions - the kind of culture, in other words, which constitutes the key for entry into modern nation- (and state-) hood. While intellectuals initially chose to focus their attention on the "high culture" of written Kurdish literature, especially in the period following the First World War attention shifted towards oral and folk culture - including dengbêjs' kilams and tales - as the main source for what was understood to constitute Kurdish cultural heritage (Strohmeier 2003: 151-154). Among the most important efforts at documenting this heritage-to-be were those undertaken by Celadet Bedirkhan, who published - in close scholarly exchange with French Orientalists like Thomas Bois and Roger Lescot - orally collected stories, fairy tales, riddles and songs in his journal Hawar in Damascus during the 1930s (Fuccaro 2003: 206-209). This early emphasis on the significance of orally transmitted literature secured the figure of the dengbêj a central place within an evolving understanding of Kurdish culture, although not yet in the paradigmatic fashion that has characterized the tradition's more recent revival.

8 With the often violent suppression of any Kurdish cultural and intellectual activity beginning in the last years of the Ottoman Empire and taking on intensified and systematic shape under the Kemalist regime of the Turkish Republic, it took until the latter half of the twentieth century for a revival of Kurdish cultural activities to take place, now in the framework of Kurdish nationalism that had been developing since the 1960s. This Kurdish political activism, as it emerged from Turkey's Left with a distinct socialist character, entailed a focus on the culture of "the people" and consequently a rather sceptical attitude towards dengbêjs, who were considered symbols of Kurdish society's feudal structure and hence of a backwards past that Kurds needed to overcome. While some voices within the Kurdish movement did advocate the collection of oral traditions and the revival of folklore as a means to construct a corpus of national culture, the dominant ideological position was that Kurdish national culture needed to be comprised of revolutionary cultural forms, which would reflect the heroic national struggle for liberation, and not of dengbêjs' epics and legends that smacked of feudalism and fairy-tale romances (Scalbert-Yücel 2009). This attitude was confirmed to me by many of my female interlocutors, who recalled that activists and Kurdish institutions had initially not shown any interest in the "old songs" [kilamên kevn] that these women knew, and that Kurdish music production, broadcasting and performance 
used to be dominated instead by popular music with political lyrics glorifying the Kurdish struggle (Aksoy 2006; Blum and Hassanpour 1996).

Beginning in the late 1990s and early 2000s this situation started to change as the result of several factors. One important element was the ideological reorientation of the PKK and the Kurdish movement more broadly after the arrest of Abdullah Öcalan in 1999, which entailed a distancing from Marxist-Leninist ideology, the official abandoning of the struggle as one directed towards the establishment of an independent nation state, and the embracement of a politics of identity focusing on the attainment of cultural and linguistic rights for Kurds in Turkey (Akkaya and Jongerden 2013). This shift in the political arena coincided with a renewed interest in dengbêjî by Kurdish writers and intellectuals, many of whom live and work in the European diaspora, and the publication of several fiction and non-fiction works about dengbêjî and/or individual dengbêjs. ${ }^{7}$ Central to the change in perception of dengbêjî has moreover been the role of institutions, most importantly the Kurdish municipalities and Kurdish cultural institutions like the Mesopotamia Cultural Centres [Navenda Çanda Mezopotamya, NÇM], which have since the early 2000s increasingly promoted dengbêjî through festivals and concerts, the opening of so-called Dengbêj Houses [Malên Dengbêjan] and other institutionalized cultural activities (Scalbert-Yücel 2009; Watts 2010: 148).

Today, only a small number of cultural centres in Turkish Kurdistan are in their entirety dedicated to dengbêjs. ${ }^{8}$ Nevertheless, in most towns established NÇMs have a section, if only a separate room or corner, allocated to dengbêjs' performances (socalled diwans). These tend to be decorated with cushions and hand woven carpets, oil lamps, water pipes and other "authentic" village objects that are considered indicative of Kurdish tradition. Dengbêjî has also experienced a revival on Kurdish television, with video clips of dengbêjs - usually shot against the backdrop of iconic landscapes taken to signify Kurdishness, such as highland pastures, remote villages or high mountain passes - being broadcasted frequently on the various music channels. Live performances of larger groups of dengbêjs, in turn, fill entire evening programmes. Dengbêjî recordings also make up a sizable proportion of the professionally distributed Kurdish music in Turkey and of the music that circulates outside the realm of copyright law, judging from the ubiquitous acoustic presence of dengbêjs' voices in both public and private spaces, emanating from cars and shops and resounding inside homes and work places (cf. Reigle 2013).

11 The dominant narrative about dengbêjî depicts the dengbêj as one or even the most important representative of Kurdish culture, thanks to whom Kurdish language, culture and history have been saved from extinction despite decades of state suppression (Scalbert-Yücel 2009). Famous dengbêjs like Evdalê Zeynikê are often described as the Homer of the Kurds, and their stories characterized as Kurdish versions of the Epic of Gilgamesh. Dengbêjs are venerated as the oral historians of the Kurdish people, as the carriers of Kurdish collective memory and the transmitters of oral literature. ${ }^{9}$ This discourse effectively posits dengbêjs not just as one, albeit central, element of Kurdish culture, but as what has allowed Kurdish culture as a whole to survive to the present day. In this way, dengbêjî is held to constitute an essential link between a Kurdish present and its past, a link that ought to be extended in order to harness a Kurdish national future (Kanakis 2013).

12 And it is this imagination of continuity, also, combined with the notion of authenticity that qualifies dengbêjî as a form of cultural heritage. Indeed, in conversations with 
dengbêjs and other cultural actors or in popular publications on the topic the terms $k$ ültür [culture] and miras [heritage, inheritance] are often used interchangeably, with both terms all too often accompanied by the attribute otantik [authentic] (cf. Kanakis 2013). Here then, we can see how a cultural practice - cultural in this instance evoking the sense of processual, "lived" culture - turns into heritage through a process of what Nathalie Heinich has felicitously termed "the administration of authenticity" (Heinich 2009: 261). As Heinich notes, such "authentic" heritage operates according to a logic of inscription: because heritage is held to provide continuity between past and present, its object requires some sort of fixation (Heinich 2009: 24). The emergence of dengbêjî as an abstract noun is only one effect of such fixation; others include, for example, the evolving notion of "original" as opposed to "faulty" kilams and the slow (though nonetheless contested) standardization of a canon of recognized dengbêjs, repertoires and styles. Another effect is that dengbêjî has come to be virtually an umbrella term used in order to describe almost all Kurdish performers of sung poetry and prose. While the term dengbêj used to be local to the region of Serhat, ${ }^{10}$ increasingly performers from other regions who are often locally known under terms such as stranbêj [singer] or şair [poet] have appeared under the label "dengbêj" when addressing supra-local audiences through Kurdish media outlets or their record covers (Çakır 2011: 52-53). Dengbêjî, in its function as virtually the most important instantiation of Kurdish culture - itself modelled on a paradigm of heritage - has thus come to bear the promise of bestowing the authority of authenticity while at the same time allowing for ready recognisability amongst broad audiences.

\section{Negotiating Kurdish cultural heritage: Between political and depoliticized culture}

This construal of dengbêjî as cultural heritage and thus as a delimited and relatively fixed entity has allowed for dengbêjî to turn into an object of debate whose relations to politics may be envisioned in radically different ways. Before I go on to explore some of these different positions in more detail, let me briefly note how the particular conceptualization of dengbêjî as cultural heritage that I have outlined here is crucially linked to liberal forms of governance. Understood as the primordial attribute of an authentic ethnic community moving through the continuous and linear time of the nation, cultural heritage and "culture" more broadly crucially contributes to qualifying the community in question for liberal forms of representation and recognition. Within liberalism, the notion of cultural heritage thus hinges on what Jeremy Walton has termed a "primordialist logic of identity in relation to civil society and political action" (Walton 2013: 190). What Walton expresses here is the idea that in a liberal framework identity, because it is imagined as natural and authentic, is construed as essentially prepolitical. Nevertheless, it simultaneously constitutes a crucial criterion for communities to be able to claim rights of recognition within the political arena of the modern nation state. Walton moreover identifies such an understanding of identity as integral to a "romantic," idealized imagination of civil society as a sphere distinct from political society and (corrupting) state power. As I want to suggest, Hatice's rejection of politics indicates a similar "romance of civil society" as that described by Walton in relation to Islamic civil society institutions in Turkey. But in order to advance this argument further it is necessary to spell out in some more detail how other actors 
within the political and cultural landscape at stake here - chiefly the Turkish state and the Kurdish movement - have envisioned the relation between cultural heritage and politics in different ways. To begin with, for the Kurdish movement dengbêjî represents an inherently and inescapably political practice. The premise here is that cultural heritage is by definition political since it marks the pristine and authentic identity of an ethnic community that by virtue of being endowed with such an identity is able to claim political representation and recognition, be it in the form of self-determination, autonomy, or even nationhood. This is the understanding of cultural heritage that Dacia Viejo-Rose, Yudhishtir Raj Isar and Helmut K. Anheier point to when they note:

Today, having a heritage is indispensable to having an identity and cultural memory; losing a heritage is like losing a key bit of both. Heritage has come to be used as 'proof' of past, tradition, belonging, and therefore proof also of rights to place, representation and political voice. (Viejo-Rose et al. 2011: 9) ${ }^{11}$

Take, for example, the following remark by Esra, a young university student from Tatvan with close ties to Kurdish political organizations, which poignantly brings to the fore precisely such an understanding:

[Dengbêjî's] political aspect is immense because it is my essence [asıl]... The fact that it is in Kurdish is already politics. That it speaks of Kurdish history is another kind of politics. [...] That we lay claim to it [sahip çımamız], that we are Kurdish adds yet another meaning to it.

16 For Esra dengbêjî, because it constitutes the essence of Kurdishness, is a political matter by definition. What accounts for this inevitable link between Kurdishness and the political is of course the fact that any expressions of Kurdishness have been brutally and systematically suppressed by the Turkish state throughout most of its history. Esra's remark is thus placed on a terrain that has been decisively structured by the Turkish state, a terrain that is marked by the decade-long ban on the production and circulation of Kurdish music and by a continuing surveillance of Kurdish musical and cultural activity, regularly leading to convictions of musicians, including dengbêjs, as well as other cultural figures on charges of supporting terrorism. ${ }^{12}$ By continually reading any cultural expression that makes reference to Kurdishness as a marker of political difference and subsequently criminalizing it, the state has thus effectively put in place the very conditions under which attempts at Kurdish heritage-making are able to take place. Note, however, that this criminalization of Kurdish cultural activity on the part of the state is equally based on an understanding of culture as the prime marker of primordial ethnic difference - a difference, which the state fears is readily translatable into political difference. Both the Turkish state's and the Kurdish movement's cultural policies are thus driven by a common understanding of what culture constitutes - primordial and collective ethnic identity - and how this makes for its privileged relation to politics.

More recently however - and arguably coinciding with the rise to power of the Islamist Justice and Development Party (AKP) - observers have noted a turn of Turkish state politics away from its Kemalist insistence on national homogeneity towards a peculiar form of (neo)liberal multiculturalism. Of specific significance in this regard has been the AKP's so-called "democratic opening" [demokratik açllım] launched in 2009, which has entailed the (often highly selective and partial) recognition of a number of rights held by Turkey's ethnic and religious "minorities" as well as a more general rhetoric of cultural and religious pluralism (cf. Casier et al. 2013). With regards to dengbêjî, the 
new pluralist rhetoric in the wake of the "Kurdish opening" [Kürt açlliml] in particular has manifested itself in a veritable embrace of the practice by the state as a demonstration of its newly found tolerant stance towards its largest ethnic "minority," the Kurds. Thus, over recent years, state authorities and AKP-run municipalities have, for example, organized numerous public performances featuring dengbêjs while dengbêjî performances have also become a central element of programmes aired on TRT Kurdî (formerly TRT6), Turkey's state TV channel broadcasting in Kurdish that was established as part of the "Kurdish opening."

Yet, as critics of liberal multiculturalism have repeatedly noticed, tolerance is here extended only on the condition that the object to be tolerated remains within boundaries determined by the tolerant majority itself (Ahmed 2000; Brown 2009; Povinelli 2002). In contemporary Turkey, the boundaries that define such a domain of tolerability revolve, as Banu Karaca has noted, around what "can be construed as threatening the territorial integrity, and thus the sovereignty, of the Turkish state" (Karaca 2011: 156). This preoccupation with national integrity has a long-standing historical legacy in Turkish political culture and is frequently dubbed the "Sèvres Syndrome." ${ }^{13}$ Nevertheless, the particular limits of what is deemed tolerable remain "unclearly mapped" writes Karaca (2011: 158) and in this way allow for arbitrary state sanctioning of any cultural or artistic practice as soon as the latter is perceived to be threatening to Turkish state sovereignty. As Casier, Jongerden and Walker argue in their discussion of the AKP's "Kurdish opening," this is a mode of politics that belies a security-focused approach to the Kurdish question which ultimately results in narrowing the political arena for pro-Kurdish politics rather than opening it up (Casier et al. 2013: 160). The ambiguity surrounding what public expressions are deemed intolerable by the Turkish state that Karaca points to also accounts for the fact that dengbêjs are regularly invited to Turkish state television and their performances heralded as an indication of the state's turn to ethnic and cultural tolerance, while they simultaneously continue to be legally persecuted for singing about their experiences of political violence. ${ }^{14}$ The limits of the speakable - and hence the point where the performance of cultural heritage turns from a depoliticized display of folklore into a political statement in support of separatist terrorism in the eyes of state authorities thus clearly run, with regards to the Kurdish community, alongside a history of statesponsored violence.

What I would like to emphasize, however, is that the state's turn to the enactment of depoliticized displays of "minority" cultural heritage in crucial ways hinges on the same basic understanding of culture as does the notion of culture's inherent political nature: in both cases culture (or cultural heritage) is understood as the prime marker of authenticity and ethnic difference. In case of the former, however, such difference is construed as an ultimately private one, therefore rendering it immune from the realm of political contestation and, in its supposed naturalness, also immune from being questioned as to the historical, economic and political conditions of its construction (Stolcke 1995; Wright 1998), which in turn allows for the kind of commercial and touristic heritage display critiqued by numerous analysts (e.g. AlSayyad 2001; Herzfeld 1991; Öncü 2007).

One consequence of the move towards liberal multiculturalist forms of governance on the part of the Turkish state has been that maintaining the sense of Kurdish cultural heritage as an inherently political category constitutes an ongoing struggle waged on 
the part of the Kurdish movement, putting constant pressure on all actors in the purview of the movement to display and prove their political allegiance to the latter. This has led to a fierce policing of political community boundaries, with accusations of treason being not uncommon (Gurbuz 2012). Artists who "collaborate" with state institutions like TRT Kurdî, for example, are frequently sanctioned from performing at events organized by Kurdish cultural institutions and often have their video clips removed from party-aligned TV channels. ${ }^{15}$

21 Yet the radical political stance of the Kurdish movement has not remained uncompromised either. No matter their political affiliation, given the virtual absence of state funding for explicitly Kurdish arts and culture in Turkey, Kurdish cultural actors are pressed hard to conform to the bureaucratic structures of potential sponsors (mainly the EU and other Western European institutions) and the normative models these entail. As Karaca (2010) has shown, due to this general dependency on external funding, the promotion of liberal multiculturalist agendas with their depoliticized visions of culture on the part of both governmental EU agencies and European nongovernmental organizations exerts profound influence on Turkey's cultural sector. This equally holds true for Turkish Kurdistan where the situation is only exacerbated by the chronic underinvestment on the part of the central state. The resulting largescale reliance on European funding has led to a situation where BDP-led (today HDP) municipalities and other Kurdish civil society institutions often - even if perhaps unintentionally - perpetuate the normative language of liberal multiculturalism promoted by funding bodies like the EU, which frame Kurdish culture mainly as a matter of the exercise of minority rights. One effect of this kind of framing is that Kurdish cultural production comes to be read as a marker of ethnic group identity (that is, as Kurdish "culture") only, consequently foreclosing any possibility of evaluating such production as art (as a form of individual expression) (Karaca 2010; Kosnick 2007). Indeed, the frequent slippage between the terms art [huner, sanat] and culture [çand, $k$ ültür] in reference to dengbêjî which one can frequently observe in both written and spoken discourse by Kurdish cultural actors, including Hatice's remark in the opening vignette, is indicative of this tendency to regard dengbêjî primarily as a collective ethnic marker. Such a reading, in turn, is readily facilitated by the concept of cultural heritage and simultaneously chimes with the Kurdish struggle for recognition within a liberal system of governance. Moreover, the brand of multiculturalism promoted by the Turkish state through vehicles like TRT Kurdî equally performs this reading of dengbêjî as a marker of ethnic difference - a difference construed here as neither politically nor artistically consequential.

Nevertheless, despite (or perhaps rather because of) the increasing prevalence of liberal multiculturalist discourses in Turkish Kurdistan due both to policies by the Turkish state and by European funding bodies, the landscape of Kurdish cultural production remains highly politicized. It is against this complex backdrop, then, that we have to understand Hatice's rejection of politics in favour of a supposedly pristine sphere of arts and culture. Her rejection did not mean, however, that Hatice gave up on politics altogether; rather, the romanticized idea of arts and culture free from politics she evinced entailed an equally romanticized ideal of politics as a sphere of voluntary, moral commitment. 


\section{Romances of civil and political society}

together with Hatice, Cemal, a male dengbêj, and Selahattin, who introduced himself as a poet [helbestvan] and welatparêzz, ${ }^{16}$ that is, a supporter of the Kurdish armed struggle. During our journey along the coast of Lake Van, a conversation between Hatice and the two men - whom she knew only through distant common acquaintances - ensued. Hatice promptly introduced herself as "linked to the party" [giredayî partî], even though she was not in fact a party member (although an active sympathizer) and told of her family's martyrs [șehit] and of the hardships she has had to endure as a Kurdish singer as a result of repression and bullying by Turkish state authorities. It did not take long before Selahattin, in turn, started praising himself for the hundreds of poems he claimed to have written honouring guerrilla fighters and commemorating martyrs, recounting rural customs and celebrating Kurdish traditions. As much as Hatice he, too, clearly had an interest in portraying himself as an artist committed to the Kurdish struggle. In response to Selahattin's self-celebratory introduction, Hatice steadfastly maintained that politics [siyaset] and culture [çand] should be kept separate, despite the importance of personal political commitment to the struggle [dava]. What she didn't like about politics, Hatice let us know, was that many engage in it merely for their own self-interest [çikara xwe]. Most people "do politics" [siyaset dikin] in order to gain materially or to practically benefit in other ways, she announced. At this point, however, she encountered opposition from her two interlocutors: politics, they maintained, was not a business of furthering self-interest, but quite to the contrary, for a true welatparêz politics was an obligation towards their people; it was both a duty and an honour. Hatice acquiesced to this standpoint, yet maintained that there were some people within "the party"17 who only sought to further their own benefits by engaging in politics. Hatice's scepticism towards (party) politics did not mean that she thought of herself or her singing as non-political, however. Several times throughout the conversation she emphasized that singing in Kurdish and being a dengbêj in particular was "itself the biggest politics" [bi xwe siyaseta herî mezin] - a politics that she was of course devoted to. On this point, Cemal and Selahattin could only agree.

How could Hatice maintain that politics and culture ought to be kept separate, only to reiterate almost in the same breath that dengbêjî was itself a form of politics? The answer is related, I think, to the construction of dengbêjî as a sphere of prepolitical cultural essence as I have outlined it above - a construction which allowed Hatice to simultaneously maintain two romances: one of civil and one of political society, which effectively worked to reinforce each other. On the one hand, Hatice displayed a vision of cultural activity as "an apolitical domain of authentic desires and identities, entirely separate from the messy turf of political society" (Walton 2013: 183). This vision came to the fore, for example, in her criticism of other dengbêjs for replacing the traditional lyrics of their kilams with political ones (celebrating the guerrilla struggle or commemorating a particular martyr, for example) while maintaining the kilam's original makam, melody and intonation. She considered such changes to be "disrespectful" [saygisiz] towards the original kilam and therefore indicative of a lack of appreciation of the authenticity inherent in cultural heritage. Based on the same premises Hatice, like many other dengbêjs, would also regularly voice criticism towards the Kurdish movement's long neglect of the dengbêjî tradition in favour of explicitly 
political music that had dominated the movement's cultural politics until the early 2000s.

Since this vision of dengbêjî as a prepolitical sphere of pristine and authentic cultural heritage effectively worked not only to erect a romantic view of civil (or cultural) society but also to infallibly prove its own premises - that is, the pettiness of its other, political engagement - it simultaneously made for the cultivation of what one may want to call the romance of political society. This was a vision of political society as one in which political activity would be premised on personal, moral commitment and not on a purely instrumental logic of personal benefit (cf. Kuzmanovic 2012). To elucidate this logic further, let me refer to the remarks by Mehmed, a Kurdish intellectual, whom I met at a little Kurdish bookshop in Istanbul. During our conversation about Kurdish music he showed himself very critical of the politicized nature of much contemporary Kurdish literature and music. "They [Kurdish musicians] have learnt that whenever they make the victory sign [zafer işareti] ${ }^{18}$ they get applause from the audience. So that's what they do, they write political lyrics and include political symbols," he remarked cynically. The politicization of Kurdish arts and culture meant that what was actually important about artistic production in Mehmed's opinion, namely the artistic content, was neglected in favour of explicitly political messages, which he regarded as having a corruptive influence on the former. Yet what Mehmed criticized was not only that arts and culture as ostensibly autonomous domains had become usurped by politics, leading to a concomitant neglect of artistic quality, but also that political lyrics and symbols did not even reflect genuine political commitment on the part of the artists. The problem, according to him, was that politics sells and that it was used in an instrumental meansends relationship for precisely such purposes. What interlocutors like Hatice and Mehmed thus rejected was the use of culture as a means for political ends while they simultaneously upheld that cultural production is inescapably a political matter in the context of Turkish Kurdistan.

Importantly, the ideal of politics purported here - an ideal that regards politics as a matter of personal and voluntary, moral commitment - hinges on the liberal idea of a self-determined individual subject whose authentic and essentially prepolitical opinions and desires constitute the source of motivation for entering political society (Kuzmanovic 2012: 22-26). But in their romanticized view of political commitment, Hatice and Mehmed also reflected the contemporary reality of everyday life in Turkish Kurdistan that has become so thoroughly politicized as a result of Turkish state politics and the Kurdish movement's politics of opposition that subjects stand under the constant pressure of having to continually profess and display their political allegiance in both public and private spheres (cf. Gurbuz 2012). And it is this very logic which works to put at risk the moral high ground of political activism promoted by the Kurdish movement by potentially emptying political action of sincere, "interior" commitment, given that individuals may engage in it simply in response to "exterior" social pressure (cf. Taylor 1991).

It is such mutually reinforcing "romantic" conceptualizations of both civil and political society, I suggest, that allowed Hatice to simultaneously maintain that dengbêjî ought to be separate from politics and that it was in fact a form of politics: only by keeping it separate from a corrupted form of politics that relied on an instrumental means-ends logic could dengbêjî remain truly political by virtue of its nature as the marker of 
authentic Kurdishness - in turn understood to be an inherently political and indeed moral condition.

\section{Promises of autonomy and gendered spaces of manoeuvre}

This leaves one question unanswered, however. Why did Hatice cling to a vision of dengbêjî as separate from politics - thereby potentially reiterating the logic of the state's depoliticizing politics of multiculturalism - given that subscribing to the Kurdish movement's culture-as-politics model (like her interlocutor Selahattin had done, for example) could have been in many ways the easier option? What did the appeal to cultural heritage as a space autonomous from politics afford her and others that I found to be reasoning in similar ways?

First of all, part of Hatice's motivation seemed to lie in gaining a space of agency outside both the realms of the Kurdish political movement and that of the Turkish state. Evoking cultural heritage as an autonomous sphere carried the promise of a degree of independence from the obligations and duties each side imposed on its supporters. As much as working for the party was perceived by welatparêz Kurds as a honourable commitment, it was also clear that it was an onerous one. Not only Hatice, but many other Kurdish women and men I knew who worked either paid or unpaid for the party at lower levels such as local assemblies, councils or party-associated cultural organizations and cooperatives talked (and sometimes complained) about the sacrifices party work demanded: one had to be ready to conduct house visits in the neighbourhood to mobilize supporters until late at night, one was expected to deliver condolences to martyr families, one was obliged to attend demonstrations in faraway cities and the like. Many of these activities were moreover risky in the sense that they could easily lead to legal prosecution. The risk incurred and the sacrifices shouldered were for many a source of honour accompanied by a sense of patriotic duty, but they were also talked about with anxiety and often with a yearning for a "normal" life outside the rigour which permanent political mobilization demanded.

Moreover, as much as being associated with the party gave individuals and associations access to financial funds and crucial personal and institutional relations, it also meant that other networks of relations outside the political hegemony of the Kurdish movement were cut off. Trying to carve out a space outside the logic of political allegiance based on the alleged autonomy of culture therefore held the promise of allowing for a space of action where different relations and new associations might be possible. ${ }^{19}$ In practice, however, the sought-for space of action only seldom opened up: instead of allowing for new relations, trying to steer free of both sides often rather led to further isolation. In her attempt at keeping her cultural activities out of politics, Hatice, for example, was confronted with the difficulty of not receiving any kind of funding - neither from the party, because she refused to formally associate with them, nor from the state, because she was too politically active and outspoken. As a result, the attempt at dissociating herself from either political side only highlighted the net of dependencies Hatice found herself in fact embedded in. The freedom of manoeuvre, which the autonomy of culture promised, was thus rarely fulfilled: the politicization of everyday life continually claimed back any autonomous space actors like Hatice laboriously sought to carve out. 
Secondly, Hatice's attempts at invoking the liberal ideal of prepolitical cultural heritage speaks of an attempt at tapping into the legitimating authority the authenticity of culture potentially conferred. This was particularly salient for female dengbêjs, since many of them were faced with various restrictions concerning singing in public, or even just singing outside their own homes in the presence of (male) strangers. For a number of reasons, which I will not be able to explore in any detail for the sake of brevity here, women's voices are associated to various degrees with the notion of shame [şerm, ayıp]..$^{20}$ This means that especially women dengbêjs of an older generation have to confront a considerable amount of (sometimes even violent) opposition, mainly by their male kin, when they seek to sing in spaces where their voices can be overheard by strangers, let alone the broader public. In this context the discourse of dengbêjî as representing the essence of Kurdish culture - paired with an equally powerful discourse about Kurdish women's central role in ensuring the survival of the Kurdish language as a mother tongue (Çağlayan 2012) - allows women to cast themselves as the authentic bearers of Kurdish culture. Such a move, in turn, worked to legitimate women dengbêjs' quest to sing in public as it allowed connecting the practice of dengbêjî to the political agenda of the Kurdish movement precisely on the basis of the culture-as-politics notion I outlined above. Thus, when women dengbêjs told me, for example, that it was wrong to think of women's voices as shameful, they would add that all they were doing, after all, was to recount Kurdish history. Was this not an honourable deed, which could only help the Kurdish cause? Here, we see how the transformation of a "living" oral tradition into what one might easily criticize as "dead" cultural heritage can actually become a dynamic nexus of gendered engagement. As David Berliner has noted in a different context, "instead of stopping transmission and culture mechanisms, heritage recognition creates aesthetic forms, historical narratives, politics of transmission, and, more generally, new social configurations" (2012: 771).

\section{Conclusion}

In their discussions of different Alevi attempts at attaining legal, political and religious recognition in contemporary Turkey both Jeremy Walton and Kabir Tambar have highlighted the ambiguities and paradoxes surrounding liberal pluralism in this particular national context. Since in Turkey pluralism constitutes "an incipient rather than an entrenched mode of governance," Tambar notes, it may well provide a "critical perspective on state practice" (2010: 653). Similarly, Walton has suggested that "in contexts such as Turkey, defined by a strong state tradition" the nongovernmental politics called for by liberal-pluralist imaginations of civil society "is not a fait accompli but an achievement" (Walton 2013: 184) - an achievement which, he furthermore notes, may take on counterhegemonic valence. Applying this insight to the political landscape of Turkish Kurdistan, I have argued that in this particular context advocating the practice of dengbêjî as a form of cultural heritage that ought to be separate from politics similarly constitutes an achievement, given that it goes against the grain of established modes of governance as they are enacted both by the Turkish state and the Kurdish political movement.

What nevertheless unites the various actors engaged in current debates about dengbêjî and its status as Kurdish cultural heritage - from those who imagine dengbêjî as 
inherently political to those who to the contrary regard it as entirely autonomous from politics - is a conceptualization of the latter as the essence of an authentic, primordial identity that stands logically and temporally prior to politics. It is this shared understanding which makes possible at all recurring debates about the ways in which dengbêjî ought to relate to politics: whether it ought to provide the legitimizing basis for political claims or whether it ought to be autonomous from governmental politics. Today, an increasing number of Kurdish cultural actors not directly aligned with the Kurdish political movement advocate the latter: like Hatice or Münevver, their discourses and practices rely on liberal ideas that posit institutions and practices of civil society (here, in particular, the world of arts and culture) as distinct from state power in an idealized way - an idealization Walton aptly calls "the civil society effect." Yet, as I have argued, this idealization of civil society does not amount to a departure from political commitment altogether. Quite to the contrary, it goes hand in hand with an idealization of oppositional politics as a sphere of personal and sincere moral commitments - an imagination that in turn hinges on liberal ideas about the selfwilled, authentic individual.

However, characterizing the attempts by women dengbêjs like Hatice at rendering dengbêjî autonomous from governmental politics as a counterhegemonic achievement should not be taken to imply that the kind of project Hatice was engaged in could take shape outside the purview of state governance. Doing so would in fact only replicate the civil society effect. Given Turkey's more recent turn to liberal multiculturalism, the invocation of cultural heritage as autonomous from politics - even if doing so in the name of commitment to an oppositional political struggle - inevitably has to risk becoming complicit in perpetuating the Turkish state's regime of administering public (un)speakability.

\section{BIBLIOGRAPHY}

Abu-Lughod, Lila (1999) Veiled Sentiments: Honor and Poetry in a Bedouin Society, Berkeley, University of California Press.

Ahmed, Sara (2000) Strange Encounters: Embodied Others in Post-Coloniality, London, Routledge.

Akkaya, Ahmet Hamdi; Jongerden, Joost (2013) “Confederalism and Autonomy in Turkey: The Kurdistan Workers' Party and the Reinvention of Democracy", in Gunes, Cengiz; Zeydanlioglu, Welat (eds.), The Kurdish Question in Turkey: New Perspectives on Violence, Representation and Reconciliation, Oxon, Routledge, pp. 186-204.

Aksoy, Ozan E. (2006) “The Politicization of Kurdish Folk Songs in Turkey in the 1990s”, Music and Anthropology: Journal of Musical Anthropology of the Mediterranean 11. URL: http://umbc.edu/MA/ index/number11/aksoy/ak_0.htm

AlSayyad, Nezar (2001) "Global Norms and Urban Forms in the Age of Tourism: Manufacturing Heritage, Consuming Tradition”, in AlSayyad, Nezar (ed.), Consuming Tradition, Manufacturing Heritage: Global Norms and Urban Forms in the Age of Tourism, London, Routledge, pp. 1-33. 
Berliner, David (2012) “Multiple Nostalgias: The Fabric of Heritage in Luang Prabang (Lao PDR)", Journal of the Royal Anthropological Institute 18 (4), pp. 769-786. URL: http://dx.doi.org/10.1111/j. 1467-9655.2012.01791.x

Blum, Stephen; Hassanpour, Amir (1996) “'The Morning of Freedom Rose Up': Kurdish Popular Song and the Exigencies of Cultural Survival”, Popular Music 15 (3), pp. 325-343. URL: http:// dx.doi.org/10.1017/S026114300000831X

Brown, Wendy (2009) Regulating Aversion: Tolerance in the Age of Identity and Empire, Princeton, Princeton University Press.

Casier, Marlies; Jongerden, Joost; Walker, Nic (2013) “Turkey's Kurdish Movement and the AKP's Kurdish Opening: Kurdish Spring or Fall?”, in Ahmed, M.; Gunter, M. (eds.), The Kurdish Spring: Geopolitical Changes and the Kurds, Costa Meza, Mazda Publishers, pp. 135-162. URL: http:// www.academia.edu/4478363/

Turkeys_Kurdish_Movement_and_the_AKPs_Kurdish_Opening_A_Kurdish_Spring_or_Fall

Çağlayan, Handan (2012) "From Kawa the Blacksmith to Ishtar the Goddess: Gender Constructions in Ideological-Political Discourses of the Kurdish Movement in Post-1980 Turkey", European Journal of Turkish Studies 14. URL: http://ejts.revues.org/4657

Çakır, Argun (2011) The Representation of the Dengbêj Tradition in Kurdish Contemporary Popular Discourse, unpublished M.A. thesis, University of Exeter, Exeter.

Chyet, Michael L. (2003) Kurdish-English Dictionary / Ferhenga Kurmancî-Inglîzî, New Haven, Yale University Press.

Feher, Michel (2007) “The Governed in Politics”, in Feher, Michel; Krikorian, Gaëlle; McKee, Yates (eds.), Nongovernmental Politics, New York, Zone Books, pp. 12-27. URL: http://

roundtable.kein.org/sites/newtable.kein.org/files/

FEHER\%20M_THE\%20GOVERNED\%20IN\%20POLITICS.pdf

Fuccaro, Nelida (2003) "Kurds and Kurdish Nationalism in Mandatory Syria: Politics, Culture and Identity", in Vali, Abbas (ed.), Essays on the Origins of Kurdish Nationalism, Costa Mesa, Mazda, pp. 191-217.

Gurbuz, Mustafa E. (2012) “'Sold Out to the Enemy’: Emerging Symbolic Boundaries in Kurdish Politics and the Strategic Uses of Labeling Treason", European Journal of Turkish Studies 14. URL: http://ejts.revues.org/4629

Heinich, Nathalie (2009) La fabrique du patrimoine : de la cathédrale à la petite cuillère, Paris, Éditions de la Maison des Sciences de l'Homme.

Herzfeld, Michael (1991) A Place in History: Social and Monumental Time in a Cretan Town, Princeton, Princeton University Press.

Kanakis, Yiannis (2013) "Dancing the Future of Hakkari's Past, According to 9-Year-old Ayfer", in Allison, Christine; Kreyenbroek, Philip G. (eds.), Remembering the Past in Iranian Societies, Wiesbaden, Harrassowitz, pp. 113-123.

Karaca, Banu (2009) "Governance of or Through Culture? Cultural Policy and the Politics of Culture in Europe”, Focaal 55, pp. 27-40. URL: http://dx.doi.org/10.3167/fcl.2009.550103

Karaca, Banu (2010) "The Art of Integration: Probing the Role of Cultural Policy in the Making of Europe”, International Journal of Cultural Policy 16 (2), pp. 121-137. URL: http://dx.doi.org/ $10.1080 / 10286630903038899$ 
Karaca, Banu (2011) "Images Delegitimized and Discouraged: Explicitly Political Art and the Arbitrariness of the Unspeakable", New Perspectives on Turkey 45, pp. 155-183. URL: http:// research.sabanciuniv.edu/18831/1/NPT-45_Karaca.pdf

Kevirbirî, Salih (2002) Karapetê Xaço: Bir Çığlığın Yüzyılı, Istanbul, Sî Yayınları.

Kızılkaya, Muhsin (2001) Kayıp Diwan, Istanbul, İletişim.

Kosnick, Kira (2007) Migrant Media: Turkish Broadcasting and Multicultural Politics in Berlin, Bloomington, Indiana University Press.

Kuzmanovic, Daniella (2012) Refractions of Civil Society in Turkey, New York, Palgrave Macmillan. URL: http://www.palgraveconnect.com/pc/doifinder/10.1057/9781137027924

Öncü, Ayşe (2007) “The Politics of Istanbul's Ottoman Heritage in the Era of Globalism: Refractions Through the Prism of a Theme Park", in Drieskens, Barbara; Mermier, Franck; Wimmen, Heiko (eds.), Cities of the South: Citizenship and Exclusion in the 21st Century, London, Beirut, Saqi Books, pp. 233-264. URL: http://research.sabanciuniv.edu/9395/

Parıltı, Abidin (2006) Dengbêjler: Sözün Yazgısı, Istanbul, İthaki.

Povinelli, Elizabeth A. (2002) The Cunning of Recognition: Indigenous Alterities and the Making of Australian Multiculturalism, Durham, Duke University Press.

Reigle, Robert F. (2013) “A Brief History of Kurdish Music Recordings in Turkey”, Hellenic Journal of Music, Education, and Culture 4 (1). URL: http://hejmec.eu/journal/index.php/HeJMEC/article/ view/41

Scalbert-Yücel, Clémence (2009) “The Invention of a Tradition: Diyarbakır's Dengbêj Project”, European Journal of Turkish Studies 10. URL: http://ejts.revues.org/4055

Stolcke, Verena (1995) “Talking Culture: New Boundaries, New Rhetorics of Exclusion in Europe”, Current Anthropology 36 (1), pp. 1-24. URL: http://dx.doi.org/10.1086\%2F204339

Strohmeier, Martin (2003) Crucial Images in the Presentation of a Kurdish National Identity: Heroes and Patriots, Traitors and Foes, Leiden, Brill.

Tambar, Kabir (2010) "The Aesthetics of Public Visibility: Alevi Semah and the Paradoxes of Pluralism in Turkey", Comparative Studies in Society and History 52 (3), pp. 652-679. URL: http:// dx.doi.org/10.1017/S0010417510000344

Taylor, Charles (1991) The Ethics of Authenticity, Cambridge, Mass., Harvard University Press. Uzun, Mehmed (1991) Rojek Ji Rojên Evdalê Zeynikê, Istanbul, Doz.

Uzun, Mehmed (2008) Dengbêjlerim, Istanbul, İthaki.

Viejo-Rose, Dacia; Isar, Yudhishthir Raj; Anheier, Helmut K. (2011) “Introduction”, in Anheier, Helmut; Isar, Yudhishthir Raj (eds.), Cultures and Globalization: Heritage, Memory and Identity, London, Sage Publications, pp. 1-20.

Walton, Jeremy F. (2013) "Confessional Pluralism and the Civil Society Effect: Liberal Mediations of Islam and Secularism in Contemporary Turkey", American Ethnologist 40 (1), pp. 182-200. URL: http://dx.doi.org/10.1111/amet.12013/

Watts, Nicole F. (2010) Activists in Office: Kurdish Politics and Protest in Turkey, Seattle, University of Washington Press.

Wright, Susan (1998) “The Politicization of “Culture”, Anthropology Today 14 (1), pp. 7-15. URL: http://lucy.ukc.ac.uk/rai/AnthToday/wright.html 


\section{NOTES}

1. All personal names used in this article are pseudonyms.

2. Since the time of my research the BDP has established a joint party structure with the HDP [Halklarin Demokrasi Partisi] and its politicians are today running under the name of the latter. Since the party was still called BDP at the time of my research, I will refer to it as BDP throughout the article.

3. Kilam is the Kurdish term for the specific genre of sung narratives performed by dengbêjs.

4. In Kurdish, the suffix -î makes an abstract noun out of adjectives and nouns (e.g. qencî means goodness from qenc [good], or biratî means brotherhood from bira [brother]). Dengbêjî is accordingly derived from dengbêj and denotes the art or profession of being a dengbêj.

5. Michael L. Chyet (personal communication) argues that the term dengbêj goes back at least several centuries. It appears for example in the seventeenth-century romance Mem $\hat{u}$ Zîn by Ehmedê Xanî.

6. This observation has been confirmed to me by other researchers. Fethi Karakeçili (personal communication) has noted that he found the term dengbêjî to be used primarily by younger dengbêjs, mainly in order to refer to the practice as a profession and a means to earn money. Moreover, as Argun Çakır (personal communication) has noted, the grammatical type of noun formation that creates dengbêjî from dengbêj cannot be observed for Kurmanji terms denoting musicians other than dengbêjs. For instance, the terms mitirbî from mitirb (a term for Doms, a Romani people of the Middle East who are often professional musicians), hozanî or hozantî from hozan (bard or minstrel) or çîrokbêjî from çîrokbêj (storyteller) are not - or at least not in widespread - use, even though they are grammatically possible word formations of the same type as dengbêjî. This seems to indicate that it is specifically the figure of the dengbêj whose knowledge and practice have come to be the object of explicit discourse.

7. The works by Mehmed Uzun (1991, 2008), in particular, have enjoyed immense popularity amongst both Kurdish and Turkish audiences. Other works of popular non-fiction writing on dengbêjs include those by Kızılkaya (2001) and Kevirbirî (2002). In fact, the older works by Yaşar Kemal from the 1960s and 1970s, who wrote in Turkish but was of Kurdish origin, already drew inspiration from and made reference to the epics and ballads of dengbêjs, but did so in a broader framework of a multivocal Anatolian folk culture, not out of a Kurdish nationalist impetus. See Çakır (2011).

8. Most important in this regard is Diyarbakır's "Dengbêj House" [Mala Dengbêjan], opened in May 2007 as part of an EU-funded project implemented by the Municipality of Diyarbakır (ScalbertYücel 2009). In Van, a similar Dengbêj House was operative for a few years, but had been closed by the time I did my fieldwork, for reasons I was never exactly able to determine but that apparently had to do both with a lack of funding and with disagreements over the degree to which dengbêjs enrolled at the Dengbêj House ought to represent party politics. The institution was reopened - again under the auspices of the local NÇM - in early 2014. While public statements about the reopening reiterated a liberal discourse of dengbêjî as a non-political and purely cultural practice (see e.g. http://www.wanhaber.com/mala-dengbejan-yenidenacildi-191908h.htm), when talking to the few female dengbêjs enrolled at the institution they clearly indicated that they conceived of their engagement at the Dengbêj House unambiguously as a political activity in support of the Kurdish struggle.

9. See for example the works by Parilt1 (2006) or Uzun (2008).

10. Serhat is a geographical term that refers to the Kurdish inhabited high-range mountains and plateaus that lie North of the Diyarbakır plain, including Kurdish-inhabited Western Armenia and North-Western Iran. 
11. This understanding of cultural heritage as constitutive of (national) communities has, of course, a long intellectual legacy reaching back at least to Herderian ideas of nationhood, which I will not be able to spell out here. For a brief overview see Wright (1998).

12. As Siyah Bant's 2013 report on freedom of expression in the arts and censorship in the Kurdish region notes, due to Turkey's anti-terror legislation "all cultural (e.g. language) and artistic expression within the Kurdish rights struggle can be construed as illegitimate 'separatist propaganda' and hence outside of the protection of freedom of expression and the arts." The report as well as an invaluable archive of many other cases of artistic censorship in Turkey is available at www.siyahbant.org. I would like to thank Banu Karaca for bringing this initiative to my attention.

13. The term refers to the Treaty of Sèvres concluded in 1920 at the end of World War I, which envisioned a partitioning of the Ottoman Empire between Armenia, Greece, Britain, France and Italy. "Sèvres Syndrome" refers to the widespread belief in Turkey that outside forces are continually conspiring to weaken, carve up and destroy the Turkish nation, therefore requiring an unceasing attitude of vigilance and defense against such impending danger.

14. Consider for example the case of Dengbêj Gazin. She was sentenced to one year in prison for singing two Kurdish songs in 2010 in Tatvan that were deemed by the state prosecution to constitute "propaganda for an illegal organization" (i.e. the PKK). She has moreover been tried for supposedly singing songs "with separatist content" at Newroz celebrations in the same year. After a series of appeals she was acquitted in both cases in 2013. See https://www.change.org/ petitions/free-raziye-k\%C4\%B1z\%C4\%B1l-gazin-kurdish-singer-and-activist and http:// bianet.org/english/minorities/133332-two-trials-for-singing-kurdish-folk-songs (accessed 19/12/2013).

15. The most famous example of this literal "excommunication" from the realm of the Kurdish movement is probably the case of the renowned Kurdish singer şivan Perwer. See Gurbuz (2012).

16. Welatparêz in Kurdish (yurtsever in Turkish) means patriotic. It is used commonly amongst Kurds to refer to those Kurds who are supporting the armed struggle and the Kurdish movement in general as opposed to Kurds who support the AKP or the Turkish state.

17. Depending on context, this expression could refer either to the BDP (today HDP) or to the Kurdistan Workers' Party (PKK) and is extremely widespread in Turkish Kurdistan, bearing testimony to the ambiguous yet nearly omnipresent nature of the Kurdish political movement as it manifests itself in people's lives in a variety of instantiations.

18. The victory sign indicates support for the Kurdish movement.

19. One example for what kind of relations might be possible outside the entrenched logic of the political operative in Turkish Kurdistan by claiming a position of neutrality would be relations with Turkish feminists from a liberal or leftist background as well as relations with cultural organizations working on a national level with different minority groups. However, attempts at cooperation between liberal Turkish and radical Kurdish activists carry their own risks and often harbour confrontations regarding the Kurdish armed struggle and a Turkish history of colonization and systematic injustice and political violence in Kurdistan.

20. For an anthropological exploration of the dynamics of shame and honour in an Egyptian Bedouin community, particularly in relation to women's singing see the work by Lila Abu-Lughod (1999). 


\section{ABSTRACTS}

Over the last decade the art of dengbêjî [Kurdish minstrelsy] has come to be understood as the paradigmatic form of Kurdish heritage and dengbêjs concomitantly as the authentic carriers of Kurdish "culture." This article seeks to outline some of the complexities and paradoxes of this ongoing process of Kurdish heritage production as it occurs at the intersection of growing liberal multiculturalist and continuing repressive forms of governance in Turkish Kurdistan. I argue that the production of Kurdish cultural heritage as it unfolds on a highly politicized terrain relies on an understanding of heritage as a marker of collective primordial identity, which goes hand in hand with an idealization of culture as a sphere of prepolitical pristine authenticity. Moreover, this article also seeks to shed light on some of the specifically gendered dynamics involved in contemporary Kurdish heritage making by asking what promises the evocation of dengbêjî as explicitly distinct from politics may hold for a number of female dengbêjs.

\section{INDEX}

Keywords: cultural heritage, female dengbêjs, cultural policy, Kurdish movement, liberal multiculturalism

\section{AUTHOR}

\section{MARLENE SCHÄFERS}

PhD Candidate

University of Cambridge, Department of Social Anthropology

Wiener-Anspach Doctoral Fellow, Université Libre de Bruxelles, Laboratoire d'Anthropologie des Mondes Contemporains (LAMC)

ems66@cam.ac.uk 